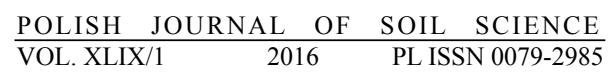

DOI: $10.17951 /$ pjss/2016.49.1.49

\title{
ANETTA SIWIK-ZIOMEK*, JOANNA LEMANOWICZ* THE INFLUENCE OF FERTILIZATION WITH PHOSPHORUS, SULPHATE, CARBON AND NITROGEN CONTENT ON HYDROLASES ACTIVITIES IN SOIL
}

\begin{abstract}
The paper presents the results of the study connected with determining the contents of total organic carbon (TOC), total nitrogen $(\mathrm{TN})$, available phosphorus $\left(\mathrm{P}_{\mathrm{E}-\mathrm{R}}\right)$, sulphate sulphur ( $\mathrm{S}_{-} \mathrm{SO}_{4}{ }^{2-}$ ), and the activity of acid phosphatase (AcP) and arylsulphatase (ARS) in Haplic Luvisol $(\mathrm{LVh})$ fertilised with varied farmyard manure (FYM) doses $\left(0,20,40,60,80 \mathrm{tha}^{-1}\right)$ and nitrogen in the form of ammonium nitrate $\left(\mathrm{N}_{0}, \mathrm{~N}_{1}, \mathrm{~N}_{2}, \mathrm{~N}_{3}\right)$. The experiment involved a 4-year crop-rotation (2005-2009). A significant effect of fertilisation with farmyard manure (FYM), ammonium sulphate and the selection of crops in crop rotation on the content of TOC and TN was found. The content of phosphorus available to plants was significantly higher in the soil sampled in the third year of research under spring barley fertilised with the FYM at the dose of $60 \mathrm{tha}^{-1}$ and nitrogen at the dose of $\mathrm{N}_{2}$. The activity of acid phosphatase in soil increased with increasing nitrogen doses. The mean amount of sulphates classifies the soil as representing a very high richness and guarantees a good supply of plants with that nutrient. The greatest activity of arylsulphatase was reported in the samples of the soil fertilised with the FYM at the amount of $80 \mathrm{~kg} \mathrm{ha}^{-1}$.
\end{abstract}

Keywords: Arylsulphatase $\bullet$ Crop rotation $\bullet$ Fertilization $\bullet$ Macroelements $\bullet$ Phosphatase

\section{INTRODUCTION}

All cells originated in soil from microbial, plant and animal release of enzymes lysis or from physiological reasons and upon cell death (Gianfreda and Ruggiero 2006). Soil is rich in enzymatic proteins that catalyse reactions

* Sub-Department of Biochemistry, Faculty of Agriculture and Biotechnology, University of Technology and Life Sciences, 85-029 Bydgoszcz, Bernardyńska 6, Poland. 
involved in energy transfer, nutrient cycling, environmental quality and crop productivity (Dick 1994; Tabatabai 1994; Liu et al. 2010). The free enzymes are usually in a complex with humic colloids and may be stabilized on clay surfaces and organic matter (Boyd and Mortland 1990). The activity of any enzyme in soil is the result of synthesis, persistence, stabilisation, regulation, and catalytic behaviour of the enzymatic proteins, present in the soil environment at the moment of the assay. All the indicated processes may be dynamically interrelated and influenced by changes in the physical, chemical, and biological soil factors (Gianfreda and Ruggiero 2006). Enzyme activities are often used as early indicators to monitor the microbial response to soil amendments and to evaluate the sustainability of land management practices (Dick et al 1994; Nannipieri et al.2011). As underlined by Alkorta et al. (2003); Schloter et al. (2003) soil enzyme activity is, "the ideal soil microbiological and biochemical indicator to determine soil quality that is easy to measure and should work equally well with other environments and reliably reveal which problems existed there".

The hydrolysis of varied orto-phosphate esters takes place with for example acid phosphatase (EC 3.1.3.2.) (Żebrowska and Ciereszko 2009; Samuel et al. 2010). Sulphur in soil occurs in an organic and inorganic form. A considerable part of organic sulphur in soil is made up by the ester compounds. During their hydrolysis the O-S bond undergoes splitting by enzyme arylsulphatase (EC 3.1.6.1.) (Tabatabai and Bremner 1970). Organic and natural fertilisation, by supplying substrates to biochemical reactions and constituting the sources of carbon for soil microorganisms triggers the enzymatic activity of soil. Mineral fertilisation stimulates biochemical reactions in soils, but also provides anions, the excessive concentration of which can inhibit enzymatic reactions in soil (Germida et al. 1992).

The aim of the present study was to evaluate the effect of the FYM fertilisation and ammonium nitrate on the changes in the content of phosphorus and sulphur fractions available to plants and total organic carbon, total nitrogen and the activity of acid phosphatase and arylsulphatase in soil in four-year crop rotation.

\section{MATERIAL AND METHODS}

\section{Site description and experimental design}

The experiments were performed on a many-year permanent experimental field located in the area of the Agricultural Experiment Station at Grabowo, in the Mazowieckie Province, Zwoleński county, Przyłęk commune $\left(.51^{\circ} 21^{\prime}{ }^{\prime}\right.$ 'N, $21^{\circ} 40^{\prime} 8$ "E). The field experiment was established in 1980 by the Department of Plant Nutrition and Fertilisation, the Institute of Soil Science and Plant Cultivation in Puławy. The ordeal was carried out with the split-plot design in 4 reps covered 
4-year crop-rotation: potato, winter wheat + intercrop: white mustard, spring barley + undersown crop of grasses, red clover + undersown crop of grasses. The investigated soils were classified as Haplic Luvisols (LVh) according to the Polish Soil Classification, light loamy and sand texture according to USDA soil classification. The experiment was set up with the split - plot method, where the first factor involved farmyard manure (FYM) fertilisation at the doses of: 0, 20, 40, $60,80 \mathrm{t} \mathrm{ha}^{-1}$. FYM was applied every four years under potatoes. The second factor was nitrogen fertilisation in a form of ammonium nitrate $(34 \% \mathrm{~N})$ at the doses of: $\mathrm{N}_{0}, \mathrm{~N}_{1}, \mathrm{~N}_{2}, \mathrm{~N}_{3}$, where the doses $\mathrm{N}_{2}$ and $\mathrm{N}_{3}$ are respective multiples of the dose $\mathrm{N}_{1}$. $\mathrm{N}$ in crop rotation are: $45 \mathrm{~kg}$ under potato, $40 \mathrm{~kg}$ under winter wheat and under mustard, $30 \mathrm{~kg}$ under spring barley with undersown crop and in total for 3 cuts $120 \mathrm{~kg}(3 \times 40 \mathrm{~kg})$ under the mixture of clover with grasses. In total during a single rotation in treatments $\mathrm{N}_{1}$ with mineral fertilisers $170 \mathrm{~kg} \mathrm{~N}$ was introduced into soil in crop rotation. Phosphorus fertilisers (granulated triplesuperphosphate- $46 \%$ $\mathrm{P}_{2} \mathrm{O}_{5}$ ) and potassium fertilisers (60\% potassium salt) were used at the same doses in all the experimental treatments: potato: $24 \mathrm{~kg} \mathrm{ha}^{-1}$ of P, $99 \mathrm{~kg} \mathrm{ha}^{-1}$ of $\mathrm{K}$, winter wheat: $21 \mathrm{~kg} \mathrm{ha}^{-1}$ of P, $60 \mathrm{~kg} \mathrm{ha}^{-1}$ of K, spring barley: $24 \mathrm{~kg} \mathrm{ha}^{-1}$ of P, $72 \mathrm{~kg} \mathrm{ha}^{-1}$ of $\mathrm{K}$, red clover: $24 \mathrm{~kg} \mathrm{ha}^{-1}$ of $\mathrm{P}, 132 \mathrm{~kg} \mathrm{ha}^{-1}$ of $\mathrm{K}$.

\section{Soil properties and enzymes analysis}

The soil was sampled in third replication once a year throughout a 4-year rotation. In the dried and sieved soil material the following ones were assayed: total organic carbon (TOC) was determined with the analyser TOC Primacs provided by Scalar, total nitrogen (TN) with the Kjeldahl method (PN-ISO $112612002)$, available phosphorus $\left(\mathrm{P}_{\mathrm{E}-\mathrm{R}}\right)(\mathrm{PN}-\mathrm{R}-04023$ 1996), sulphate sulphur according to the Bardsley-Lancaster method (Bardsley and Lancaster 1960) modified by COMN-IUNG, the activity of acid phosphatase (AcP)and arylsulphatase (ARS) with the Tabatabai and Bremner method (Tabatabai and Bremner 1969),, $\mathrm{pH}$ in $1 \mathrm{~mol} \mathrm{dm}^{-3} \mathrm{KCl}$ was determined potenciometrically (ISO 10390 2005). All the assays were made in three replicates.

\section{Statistical analysis}

The analysis of variance of multiple three-factor experiments, in split-plot design was applied to the obtained data. The significance of the differences between means was verified with the Tukey'a test at the level of significance/ confidence of $P=0.05$. For the purpose of the calculations, Microsoft Excelbased ANOVA software was applied. Besides, the results of the analyses were exposed to the analysis of simple correlation $(P<0.05)$ which determines the relationship between respective characters. The analysis of correlation was made using 'Statistica for Windows Pl'. 


\section{RESULTS AND DISCUSSION}

The content of organic carbon in soil throughout the four years fell within the range of $8.75-12.8 \mathrm{~g} \cdot \mathrm{kg}^{-1}$ and depended on the FYM and nitrogen fertilisation (Table 1). The higher the FYM dose, the greater the accumulation of that important component of soil humus. The highest increase in the content of TOC was recorded in the soil samples fertilised with the highest doses of natural fertiliser (Table 1). No significant difference was noted between the content of TOC in the samples fertilised with FYM at the amount of $60 \mathrm{tha}^{-1}$ and $80 \mathrm{tha}^{-1}$. Fertilisation with ammonium nitrate affected the content of TOC.. However, with an increasing rate of the fertiliser applied no homogenous increase in the content of organic carbon was stated (Table 1).

TABLE 1. CONTENT OF TOTAL ORGANIC CARBON (TOC) AND NITROGEN (TN) IN SOIL

\begin{tabular}{|c|c|c|c|c|c|c|c|c|c|c|c|}
\hline \multirow[t]{3}{*}{ Year } & \multirow{3}{*}{$\begin{array}{c}\text { FYM } \\
\text { I factor } \\
{\left[\mathrm{t} \cdot \mathrm{ha}^{-1}\right]}\end{array}$} & \multicolumn{5}{|c|}{$\mathrm{TOC} \mathrm{g} \mathrm{kg}^{-1}$} & \multicolumn{5}{|c|}{$\mathrm{TN} \mathrm{g} \mathrm{kg}^{-1}$} \\
\hline & & \multicolumn{10}{|c|}{ Nitrogen $\left[\mathrm{kgN} \cdot \mathrm{ha}^{-1}\right]$ II factor } \\
\hline & & N0 & N1 & $\mathrm{N} 2$ & N3 & Mean & N0 & N1 & N2 & N3 & Mean \\
\hline \multirow[t]{6}{*}{2005} & 0 & 11.2 & 12.1 & 10.0 & 12.1 & 11.4 & 0.697 & 0.721 & 0.732 & 0.770 & 0.730 \\
\hline & 20 & 14.1 & 11.6 & 10.9 & 10.4 & 11.8 & 0.704 & 0.728 & 0.739 & 0.760 & 0.732 \\
\hline & 40 & 12.7 & 12.1 & 12.1 & 13.4 & 12.6 & 0.686 & 0.735 & 0.753 & 0.756 & 0.732 \\
\hline & 60 & 13.6 & 15.8 & 13.4 & 13.8 & 14.2 & 0.795 & 0.795 & 0.851 & 0.886 & 0.831 \\
\hline & 80 & 11.9 & 15.9 & 14.8 & 14.0 & 14.2 & 0.907 & 0.893 & 0.907 & 0.959 & 0.916 \\
\hline & Mean & 12.7 & 13.5 & 12.2 & 12.7 & 12.8 & 0.757 & 0.774 & 0.796 & 0.826 & 0.916 \\
\hline \multicolumn{2}{|c|}{$\mathrm{LSD}_{0.05}$} & \multicolumn{2}{|c|}{ I 1.406} & & \multicolumn{2}{|c|}{ II 0.815} & \multicolumn{2}{|c|}{ I 0.033} & & \multicolumn{2}{|c|}{ II 0.019} \\
\hline \multicolumn{2}{|c|}{ Interaction } & \multicolumn{2}{|c|}{ I/II 2.168} & & \multicolumn{2}{|c|}{ II/I1.823 } & \multirow{2}{*}{\multicolumn{2}{|c|}{ I/II n.s. }} & & \multicolumn{2}{|c|}{ II/I n.s. } \\
\hline \multicolumn{2}{|c|}{$\mathrm{SD}$} & \multicolumn{5}{|c|}{1.164} & & & \multicolumn{3}{|l|}{0.080} \\
\hline \multirow[t]{6}{*}{2006} & 0 & 8.17 & 8.49 & 8.60 & 8.23 & 8.37 & 0.889 & 0.966 & 0.924 & 0.966 & 0.936 \\
\hline & 20 & 9.06 & 8.73 & 8.86 & 9.49 & 9.03 & 0.980 & 0.947 & 0.956 & 0.956 & 0.959 \\
\hline & 40 & 9.84 & 9.51 & 10.6 & 10.6 & 10.1 & 0.991 & 1.012 & 0.942 & 0.987 & 0.983 \\
\hline & 60 & 10.7 & 10.3 & 10.2 & 9.94 & 10.3 & 0.931 & 0.970 & 0.956 & 0.921 & 0.944 \\
\hline & 80 & 10.7 & 10.5 & 10.9 & 10.2 & 10.6 & 0.959 & 0.966 & 0.980 & 1.005 & 0.977 \\
\hline & Mean & 9.70 & 9.53 & 9.86 & 9.71 & 9.70 & 0.950 & 0.972 & 0.951 & 0.967 & 0.960 \\
\hline \multicolumn{2}{|c|}{$\mathrm{LSD}_{0.05}$} & \multicolumn{2}{|c|}{ I 0.422} & & \multicolumn{2}{|c|}{ II n.s. } & \multicolumn{2}{|c|}{ I n.s. } & \multicolumn{3}{|c|}{ II n.s. } \\
\hline \multicolumn{2}{|c|}{$\begin{array}{c}\text { Interaction } \\
\text { SD }\end{array}$} & \multicolumn{2}{|c|}{$\mathrm{I} / \mathrm{II}$ n.s } & 0.893 & & & \multicolumn{2}{|c|}{ I/II n.s. } & 0.029 & & \\
\hline 2007 & 0 & 7.54 & 7.60 & 7.14 & 7.29 & 7.39 & 0.679 & 0.683 & 0.711 & 0.728 & 0.700 \\
\hline & 20 & 8.10 & 7.89 & 8.04 & 7.90 & 7.98 & 0.707 & 0.721 & 0.739 & 0.760 & 0.732 \\
\hline & 40 & 8.37 & 7.61 & 9.24 & 9.48 & 8.68 & 0.749 & 0.728 & 0.812 & 0.851 & 0.785 \\
\hline & 60 & 9.65 & 9.86 & 10.0 & 9.96 & 9.81 & 0.854 & 0.826 & 0.861 & 0.863 & 0.851 \\
\hline & 80 & 9.35 & 9.94 & 9.78 & 10.1 & 9.80 & 0.917 & 0.931 & 0.959 & 0.949 & 0.939 \\
\hline & Mean & 8.61 & 8.58 & 8.85 & 8.95 & 8.75 & 0.781 & 0.778 & 0.816 & 0.830 & 0.801 \\
\hline & $\mathrm{D}_{0.05}$ & & 0.302 & & II 0.3 & & & 0.041 & & II 0.02 & \\
\hline & action & & 0.719 & & $\mathrm{II} / \mathrm{I} 0$ & & $\mathrm{I} / \mathrm{II}$ & 0.066 & & II/I 0. & \\
\hline & $\mathrm{D}$ & & & 1.046 & & & & & 0.090 & & \\
\hline
\end{tabular}




\begin{tabular}{|c|c|c|c|c|c|c|c|c|c|c|c|}
\hline \multirow[t]{3}{*}{ Year } & \multirow{3}{*}{$\begin{array}{c}\text { FYM } \\
\text { I factor } \\
{\left[\mathrm{t}^{-} \cdot \mathrm{a}^{-1}\right]}\end{array}$} & \multicolumn{5}{|c|}{ TOC $\mathrm{g} \mathrm{kg}^{-1}$} & \multicolumn{5}{|c|}{$\mathrm{TN}_{\mathrm{g} \mathrm{kg}} \mathrm{kg}^{-1}$} \\
\hline & & \multicolumn{10}{|c|}{ Nitrogen $\left[\mathrm{kgN} \cdot \mathrm{ha}^{-1}\right]$ II factor } \\
\hline & & No & N1 & $\mathrm{N} 2$ & N3 & Mean & N0 & N1 & N2 & N3 & Mean \\
\hline \multirow[t]{6}{*}{2008} & 0 & 9.20 & 7.82 & 9.00 & 8.84 & 8.73 & 0.889 & 0.914 & 0.893 & 0.970 & 0.916 \\
\hline & 20 & 10.7 & 9.95 & 10.2 & 9.69 & 10.1 & 1.155 & 1.159 & 1.169 & 1.187 & 1.167 \\
\hline & 40 & 11.9 & 12.4 & 11.9 & 9.35 & 11.4 & 0.826 & 1.197 & 1.211 & 1.176 & 1.103 \\
\hline & 60 & 11.0 & 12.9 & 12.5 & 10.7 & 11.8 & 1.152 & 1.166 & 1.176 & 1.169 & 1.166 \\
\hline & 80 & 11.9 & 12.3 & 11.7 & 12.5 & 12.1 & 0.952 & 1.134 & 1.225 & 1.229 & 1.135 \\
\hline & Mean & 10.9 & 11.0 & 11.0 & 10.2 & 10.85 & 0.995 & 1.114 & 1.135 & 1.146 & 1.097 \\
\hline \multicolumn{2}{|c|}{$\mathrm{LSD}_{0.05}$} & \multicolumn{2}{|c|}{ I 0.705} & & \multicolumn{2}{|c|}{ II 0.413} & \multicolumn{2}{|c|}{ I 0.018} & & \multicolumn{2}{|c|}{ II 0.020} \\
\hline \multicolumn{2}{|c|}{ Interaction } & \multicolumn{2}{|c|}{ I/II 1.094} & & \multirow{2}{*}{\multicolumn{2}{|c|}{ II/I 0.924}} & \multicolumn{2}{|c|}{ I/II 0.044} & & \multirow{2}{*}{\multicolumn{2}{|c|}{ II/I 0.044}} \\
\hline & $\mathrm{D}$ & & & 1.463 & & & & & 0.129 & & \\
\hline
\end{tabular}

n.s. - not significant

The content of TN in soil ranged from 0.679 to $1.229 \mathrm{~g} \mathrm{~kg}^{-1}$ and fluctuated with fertilisation (Table 1). The lowest significant content of TN was recorded in the soil which was fertilised neither with FYM nor with nitrogen. Soil fertilisation with FYM at the doses range of 20-80 $\mathrm{t} \mathrm{ha}^{-1}$ resulted in a significant increase in the content of TN as compared with the treatments with no FYM applied. Similar conclusions were reported by Sosulski et al. (2005). Soil fertilisation with ammonium nitrate resulted in a clear increase in the content of TN in soil. The greatest content of TN was recorded in soil fertilised with nitrogen at dose $\mathrm{N}_{3}$, an increase in TN was reported as compared with the soil not fertilised with nitrogen in the year of investigation 2005, 2007 and 2008.

\section{The influence of fertilization on phosphorus and sulphur content}

The content of available phosphorus for plants ranged from 68.29 to 92.45 $\mathrm{mg} \mathrm{kg}$, with value of $81.24 \mathrm{mg} \mathrm{kg}^{-1}$ of $\mathrm{P}$ (mean values of the period 20052008) (Table 2). According to the criteria provided in PN-R-04023 (1996), the soil represents class III of high content of $\mathrm{P}_{\mathrm{E}-\mathrm{R}}$ for plants. A significant effect of the experimental factors applied on the changes of $\mathrm{P}_{\mathrm{E}-\mathrm{R}}$ in Luvisol was found. The content of available phosphorus in soil showed a positive reaction to increasing FYM doses. The highest dose $\left(80 \mathrm{t} \mathrm{ha}^{-1}\right)$ was the only one which resulted from a $4 \%$ to $15 \%$ decrease in the content of $\mathrm{P}_{\mathrm{E}-\mathrm{R}}$ in the four years of investigation. As compared with the content of that nutrient in soil sampled from FYM treatments at the dose of $60 \mathrm{t} \mathrm{ha}^{-1}$ possess the greatest content of $\mathrm{P}_{\mathrm{E}-\mathrm{R}}$ (81.72-108.5 $\mathrm{mg} \mathrm{kg}^{-1}$ of $\mathrm{P}$ of years 2005-2008). The lowest $\mathrm{P}$ content was noted in the soil not fertilised with FYM in 2005, 2006 and 2008 (indicate $63.83,71.22$ and $53.75 \mathrm{mg} \mathrm{kg}^{-1}$ respectively), while in 2007, it was recorded at a dose 20 t ha ( $\left.79.83 \mathrm{mg} \mathrm{kg}^{-1}\right)$.

Soil available phosphorus content changed significantly as a function of $\mathrm{N}$ fertilization treatments and in the entire experiment period (2005-2008). Increasing rates from $\mathrm{N}_{0}$ to $\mathrm{N}_{1}$ or $\mathrm{N}_{2} \mathrm{~kg} \mathrm{ha}^{-1}$ year ${ }^{-1} \mathrm{~N}$ gradually increased the $\mathrm{P}_{\mathrm{E}-\mathrm{R}}$ 
content in soil. A lowered concentration of $\mathrm{P}_{\mathrm{E}-\mathrm{R}}$ was observed in the soil with the fertilization nitrogen at the highest dose $\left(\mathrm{N}_{3}\right)$.

As reported by Sienkiewicz et al. (2009), a long-term FYM application clearly increases the content of available phosphorus in soil. According to these authors, the total $\mathrm{P}$ content in manure is very variable and nearly $70 \%$ of total $\mathrm{P}$ in manure is labile. Lemanowicz et al. (2014) observed a decrease in the content of $\mathrm{P}_{\mathrm{E}-\mathrm{R}}$ in soil as a result of increasing nitrogen doses which the authors refer to increasing uptake of phosphorus by plants. The effect of nitrogen can, on the one hand, be considered through its effect on yield increases and thus greater uptake of phosphorus, while, on the other hand, one shall bear in mind that high $\mathrm{N}$ doses can increase the soil acidity.

The content of phosphorus changed considerably throughout the 4-year crop-rotation. The greatest accumulation of the nutrient was reported in the soil sampled on which spring barley (year 2007) was grown (92.45 $\mathrm{mg} \mathrm{kg}^{-1}$ of P) which was 3 years after the FYM application. The usual utilisation of phosphorus from FYM ranges from 20 to $25 \%$ in the first year after its use and about $60-65 \%$ throughout the successive three years. In the fourth research year when red clover was grown there was recorded a significant decrease in the content of available phosphorus (68.29 $\mathrm{mg} \mathrm{kg}^{-1}$ of P) (Table 2).

TABLE 2. CONTENT OF AVAILABLE PHOSPHORUS $\left(\mathrm{P}_{\mathrm{E}-\mathrm{R}}\right)$ AND SULPHATES $\left(\mathrm{S}_{-} \mathrm{SO}_{4}{ }^{2-}\right) \mathrm{IN} \mathrm{SOIL}$

\begin{tabular}{|c|c|c|c|c|c|c|c|c|c|c|c|}
\hline \multirow[t]{3}{*}{ Year } & \multirow{3}{*}{$\begin{array}{l}\text { FYM } \\
\text { I factor } \\
{\left[\mathrm{t} \cdot \mathrm{ha}^{-1}\right]}\end{array}$} & \multicolumn{5}{|c|}{$\mathrm{P}_{\mathrm{E}-\mathrm{R}} \mathrm{mg} \mathrm{kg}^{-1}$} & \multicolumn{5}{|c|}{$\mathrm{S}^{-\mathrm{SO}_{4}{ }^{2-} \mathrm{mg} \mathrm{kg}^{-1}}$} \\
\hline & & \multicolumn{10}{|c|}{ Nitrogen $\left[\mathrm{kgN} \cdot \mathrm{ha}^{-1}\right]$ II factor } \\
\hline & & N0 & N1 & N2 & N3 & Mean & N0 & N1 & $\mathrm{N} 2$ & N3 & Mean \\
\hline \multirow[t]{6}{*}{2005} & 0 & 52.58 & 62.17 & 73.03 & 67.55 & 63.83 & 18.02 & 17.19 & 17.92 & 12.68 & 16.45 \\
\hline & 20 & 57.20 & 68.40 & 89.70 & 55.95 & 67.81 & 22.37 & 25.70 & 13.19 & 16.06 & 19.33 \\
\hline & 40 & 62.25 & 74.45 & 93.65 & 76.40 & 76.68 & 21.53 & 18.88 & 19.66 & 18.03 & 19.40 \\
\hline & 60 & 65.03 & 84.27 & 112.0 & 94.80 & 88.27 & 22.43 & 22.94 & 19.95 & 15.72 & 20.26 \\
\hline & 80 & 59.94 & 88.21 & 98.95 & 93.97 & 87.77 & 19.33 & 15.61 & 16.23 & 13.58 & 16.19 \\
\hline & Mean & 61.40 & 75.50 & 93.46 & 77.13 & 76.87 & 20.73 & 20.06 & 17.29 & 15.21 & 18.32 \\
\hline \multirow{3}{*}{\multicolumn{2}{|c|}{$\begin{array}{c}\mathrm{LSD}_{0.05} \\
\text { Interaction } \\
\mathrm{SD}\end{array}$}} & \multirow{3}{*}{\multicolumn{2}{|c|}{$\begin{array}{c}\text { I } 0.027 \\
\text { I/II } 0.037\end{array}$}} & & \multirow{3}{*}{\multicolumn{2}{|c|}{$\begin{array}{l}\text { II } 0.013 \\
\text { II/I } 0.029\end{array}$}} & \multirow{3}{*}{\multicolumn{2}{|c|}{$\begin{array}{c}\text { I } 1.396 \\
\text { II/I } 1.740\end{array}$}} & & \multirow{3}{*}{\multicolumn{2}{|c|}{$\begin{array}{c}\text { II } 0.524 \\
\text { I//II } 1.171\end{array}$}} \\
\hline & & & & & & & & & & & \\
\hline & & & & 16.88 & & & & & 3.487 & & \\
\hline \multirow[t]{6}{*}{2006} & 0 & 55.65 & 70.91 & 81.55 & 73.80 & 71.22 & 14.30 & 10.42 & 14.26 & 11.61 & 12.65 \\
\hline & 20 & 68.90 & 79.44 & 91.35 & 90.95 & 80.16 & 14.37 & 11.72 & 11.66 & 10.09 & 11.96 \\
\hline & 40 & 70.90 & 84.60 & 96.04 & 85.05 & 84.14 & 10.65 & 11.72 & 11.28 & 11.89 & 11.41 \\
\hline & 60 & 96.64 & 105.0 & 120.0 & 112.5 & 108.5 & 12.62 & 12.85 & 15.10 & 9.985 & 12.64 \\
\hline & 80 & 75.92 & 88.27 & 105.5 & 100.5 & 92.54 & 18.17 & 17.30 & 16.45 & 16.67 & 17.15 \\
\hline & Mean & 74.20 & 85.64 & 98.88 & 90.56 & 87.32 & 14.02 & 12.80 & 13.78 & 12.05 & 13.16 \\
\hline \multirow{3}{*}{\multicolumn{2}{|c|}{$\begin{array}{l}\mathrm{LSD}_{0.05} \\
\text { Interaction } \\
\text { SD }\end{array}$}} & \multirow{2}{*}{\multicolumn{2}{|c|}{$\begin{array}{c}\text { I } 3.597 \\
\text { I/II } 5.424\end{array}$}} & & \multicolumn{2}{|c|}{ II 2.009} & \multicolumn{2}{|c|}{ I 1.257} & & \multicolumn{2}{|c|}{ II 0.705} \\
\hline & & & & & \multirow{2}{*}{\multicolumn{2}{|c|}{ II/I 4.492}} & \multirow{2}{*}{\multicolumn{2}{|c|}{ II/I 1.900}} & & \multirow{2}{*}{\multicolumn{2}{|c|}{ I//II 1.576}} \\
\hline & & \multicolumn{2}{|c|}{ I/II 5.424} & 14.45 & & & & & 2.521 & & \\
\hline
\end{tabular}




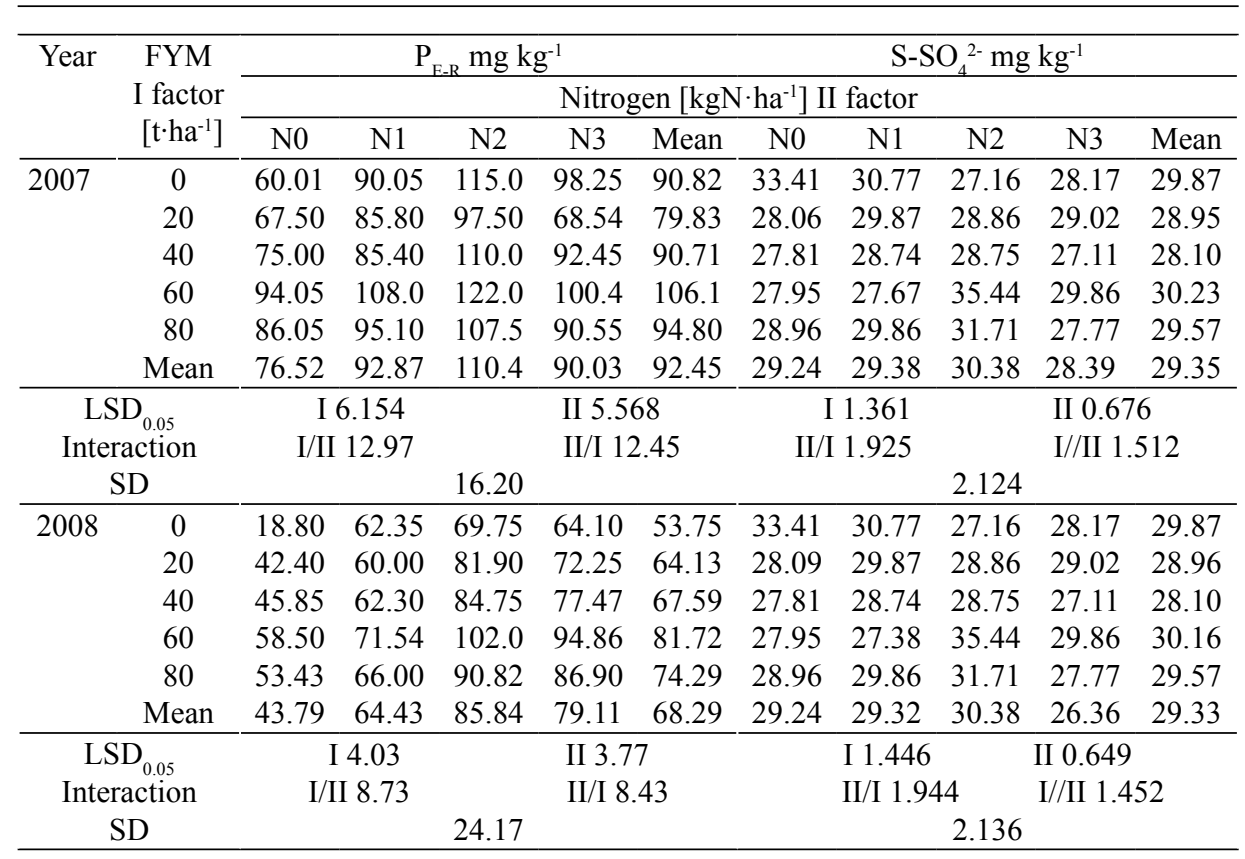

Over the last two decades sulfur (S) deficiency has been recognized as a constraint on crop production all over the world (Eriksen et al. 2004; Girma et al. 2005; Schonhof et al. 2007; Mascagni et al. 2008; Scherer 2009).

The content of sulphate sulphur in soil over four research years oscillated within wide range of $8.114-33.41 \mathrm{mg} \mathrm{kg}^{-1}$, on average for all the fertilisation treatments: $22.54 \mathrm{mg} \mathrm{SO}_{4}{ }^{2-} \mathrm{kg}^{-1}$ (Table 2). In most soils under agricultural use, the content of sulphate sulphur in Poland does not exceed $25 \mathrm{mg} \mathrm{kg}^{-1}$ of soil. Most soils, namely $70 \%$ of the agricultural acreage, demonstrate the content of that sulphur fraction ranging from 5.0 to $20.0 \mathrm{mg} \mathrm{kg}^{-1}$ (Lipiński et al. 2003). The average content of sulphates in soil in 2005-2008 (22.54 $\left.\mathrm{mg} \mathrm{kg}^{-1}\right)$ classifies it as the soil of a very high richness in that nutrient and guarantees good supply of plants (Lipiński et al. 2003). The accumulation of sulphates (VI) below $10 \mathrm{mg} \mathrm{kg}^{-1}$, observed in soil in some experimental treatments is considered low and it does not ensure the right supply of sulphur to plants. Sulphur deficit in soil makes it impossible for the plants to develop an adequate biomass yield and, at the same time, deteriorates the biological value of the yield. Sulphur deficits in soils of Poland and other countries will increase as a result of limiting the industrial $\mathrm{SO}_{2}$ emissions. Consumption of natural and mineral fertilisers containing sulphur systematically decreased. Sulphur deficit in plant production has become a problem of contemporary agriculture. especially agriculture in the northern part of Europe (Eriksen et al. 2004, Scherer 2009). Besides mineral fertilises, some amounts of sulphur are provided by natural fertilises. FYM contains from 0.9 to $1.2 \mathrm{~kg} \mathrm{ha}^{-1}$ of sulphur and it is estimated that on average $20 \%$ of total sulphur occurs in a form of sulphides 
available to plants. organic bonds account for $40 \%$ and another $40 \%$-for organic and inorganic sulphates. In the present experiment it was shown that increasing FYM doses increased the concentration of the sulphur fraction available to plants. The greatest content of sulphate sulphur similarly as the content of organic carbon was reported in the soil sampled from treatments which involved fertilisation with the FYM dose at the rate of $60 \mathrm{tha}^{-1}$ and $80 \mathrm{t} \mathrm{ha}^{-1}$ (Table 2).

\section{The influence offertilization on enzymes activities}

Based on the obtained results, the effect of the experimental factors on the change in the activity of acid phosphatase was found significant since both natural and mineral fertilisation stimulates the development of plants and soil microorganisms and also affected the soil enzymatic activity. The greatest activity ranged from 1.39 to $2.50 \mathrm{mM} \mathrm{pNP} \mathrm{kg} \mathrm{kh}^{-1}$, with value of $2.04 \mathrm{mM} \mathrm{pNP} \mathrm{kg}{ }^{-1}$ $\mathrm{h}^{-1}$ (Table 3) in the soil fertilised with FYM at the dose of $60 \mathrm{t} \mathrm{ha}^{-1}$. The FYM dose of $80 \mathrm{t} \mathrm{ha}^{-1}$ decreased the activity of acid phosphatase in soil by $5 \%$ (Fig. 1A). The lowest activity of the enzyme responsible for phosphorus transformations in soil was reported for the treatments not fertilised with FYM. According to Dodor and Tabatabai (2003); Kotkowa et al. (2008), Okur et al. (2008) a regular application of organic and natural fertilisers increases the content of carbon of organic compounds in soil and thus intensifies their biological activity and the presence of carbon substrates induces and stimulates the biosynthesis of enzymes by soil microorganisms.

TABLE 3. ACTIVITY OF ACID PHOSPHATASE (ACP) AND ARYLSULPHATASE (ARS) IN SOIL

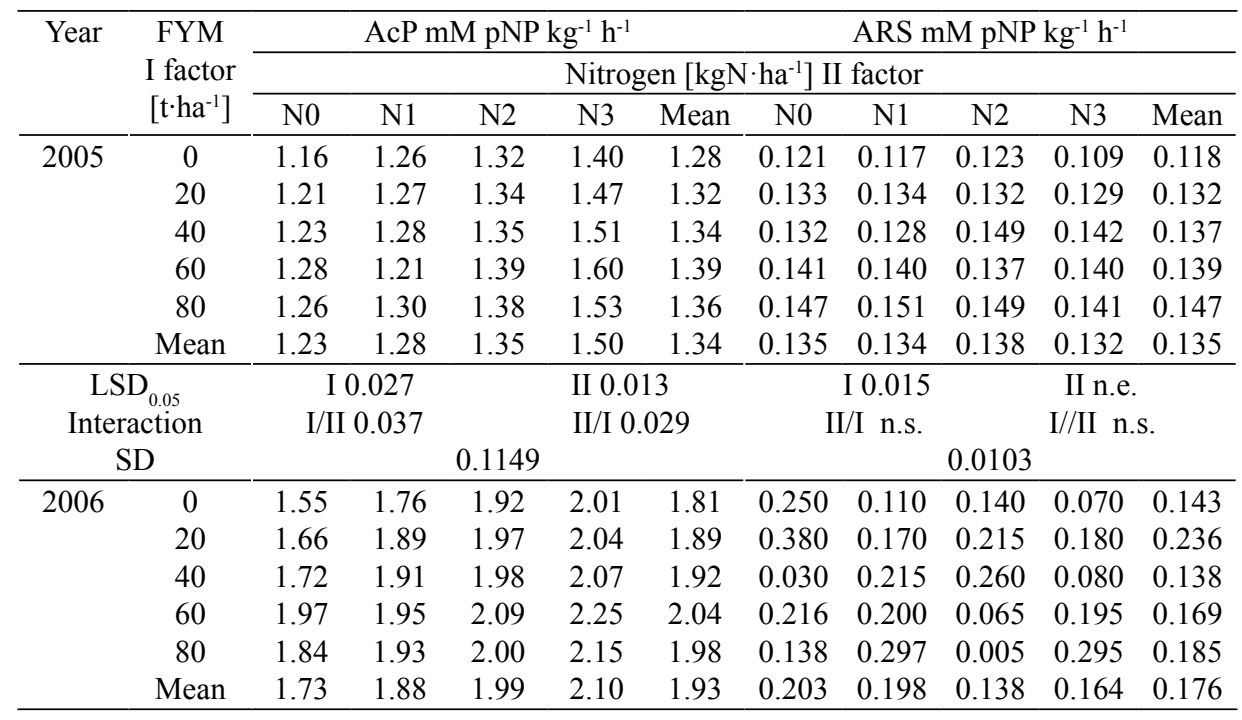




\begin{tabular}{|c|c|c|c|c|c|c|c|c|c|c|c|}
\hline \multirow[t]{3}{*}{ Year } & \multirow{3}{*}{$\begin{array}{c}\text { FYM } \\
\text { I factor } \\
{\left[\mathrm{t} \cdot \mathrm{ha}^{-1}\right]}\end{array}$} & \multicolumn{5}{|c|}{$\mathrm{AcP} \mathrm{mM} \mathrm{pNP} \mathrm{kg}{ }^{-1} \mathrm{~h}^{-1}$} & \multicolumn{5}{|c|}{ ARS mM pNP kg-1 $\mathrm{h}^{-1}$} \\
\hline & & \multicolumn{10}{|c|}{ Nitrogen $\left[\mathrm{kgN} \cdot \mathrm{ha}^{-1}\right]$ II factor } \\
\hline & & No & N1 & N2 & N3 & Mean & N0 & N1 & N2 & N3 & Mean \\
\hline \multirow{3}{*}{\multicolumn{2}{|c|}{$\begin{array}{c}\mathrm{LSD}_{0.05} \\
\text { Interaction } \\
\mathrm{SD}\end{array}$}} & \multicolumn{2}{|c|}{ I 0.033} & & \multicolumn{2}{|c|}{ II 0.019} & \multicolumn{2}{|c|}{ I 0.062} & \multicolumn{3}{|c|}{ II 0.030} \\
\hline & & \multicolumn{2}{|c|}{$\mathrm{I} / \mathrm{II} 0.051$} & & \multicolumn{2}{|c|}{ II/I 0.043} & \multicolumn{2}{|c|}{ II/I 0.086} & & \multicolumn{2}{|c|}{ I//II 0.067} \\
\hline & & & & 0.1616 & & & & & 0.0888 & & \\
\hline \multirow[t]{6}{*}{2007} & 0 & 1.51 & 1.62 & 1.84 & 2.07 & 1.76 & 0.349 & 0.210 & 0.242 & 0.093 & 0.223 \\
\hline & 20 & 1.71 & 1.89 & 2.03 & 2.19 & 1.95 & 0.484 & 0.270 & 0.312 & 0.279 & 0.336 \\
\hline & 40 & 1.90 & 2.00 & 2.12 & 2.37 & 2.09 & 0.131 & 0.316 & 0.363 & 0.144 & 0.238 \\
\hline & 60 & 2.25 & 2.45 & 2.51 & 2.80 & 2.50 & 0.312 & 0.298 & 0.163 & 0.354 & 0.282 \\
\hline & 80 & 1.85 & 2.26 & 2.36 & 2.30 & 2.27 & 0.251 & 0.396 & 0.107 & 0.396 & 0.287 \\
\hline & Mean & 1.84 & 2.04 & 2.17 & 2.41 & 2.11 & 0.305 & 0.298 & 0.237 & 0.253 & 0.273 \\
\hline \multicolumn{2}{|c|}{$\mathrm{LSD}_{0.05}$} & \multicolumn{2}{|c|}{ I 0.084} & & \multicolumn{2}{|c|}{ II 0.075} & \multicolumn{2}{|c|}{ I 0.042} & & \multicolumn{2}{|c|}{ II 0.040} \\
\hline \multicolumn{2}{|c|}{ Interaction } & \multirow{2}{*}{\multicolumn{2}{|c|}{ I/II n.s }} & & \multicolumn{2}{|c|}{ II/I n.s. } & \multicolumn{2}{|c|}{ II/I 0.092} & & \multicolumn{2}{|c|}{ I//II 0.089} \\
\hline \multicolumn{2}{|c|}{ SD } & & & \multicolumn{3}{|l|}{0.357} & \multicolumn{5}{|c|}{0.0974} \\
\hline \multirow[t]{6}{*}{2008} & 0 & 0.86 & 1.05 & 1.12 & 1.16 & 1.05 & 0.140 & 0.130 & 0.238 & 0.238 & 0.186 \\
\hline & 20 & 0.92 & 1.29 & 1.32 & 1.34 & 1.22 & 0.159 & 0.321 & 0.238 & 0.238 & 0.218 \\
\hline & 40 & 1.10 & 1.49 & 1.57 & 1.69 & 1.46 & 0.293 & 0.293 & 0.261 & 0.321 & 0.292 \\
\hline & 60 & 1.61 & 1.78 & 2.32 & 3.13 & 2.21 & 0.582 & 0.358 & 0.358 & 0.191 & 0.341 \\
\hline & 80 & 1.86 & 2.16 & 2.29 & 2.41 & 2.17 & 0.433 & 0.316 & 0.316 & 0.544 & 0.422 \\
\hline & Mean & 1.27 & 1.54 & 1.72 & 1.94 & 1.62 & 0.321 & 0.284 & 0.273 & 0.289 & 0.292 \\
\hline \multirow{3}{*}{\multicolumn{2}{|c|}{$\begin{array}{c}\mathrm{LSD}_{0.05} \\
\text { Interaction } \\
\mathrm{SD}\end{array}$}} & \multicolumn{2}{|c|}{ I 0.20} & & II 0.0 & & & I 0.059 & & II 0.03 & \\
\hline & & $\mathrm{I} / \mathrm{I}$ & 0.257 & & II/I 0 & & & //I 0.090 & & $/ / / \mathrm{II} 0.0$ & \\
\hline & & & & 0.5471 & & & & & 0.1082 & & \\
\hline
\end{tabular}

There was a significantly higher acid phosphatase activity in 2007 in the soil under spring barley (on average $2.41 \mathrm{mM} \mathrm{pNP} \mathrm{kg}^{-1} \mathrm{~h}^{-1}$ ) having applied the greatest dose $\left(\mathrm{N}_{3}\right)$ as compared to doses $\mathrm{N}_{0}-\mathrm{N}_{2}$ (Table 3). In while the lowest (on average of $1.34 \mathrm{mM} \mathrm{pNP} \mathrm{kg}^{-1} \mathrm{~h}^{-1}$ ) in the soil sampled under potato (2005 year). The growing nitrogen fertilisation increased the activity of acid phosphatase. Having applied the greatest dose $\left(\mathrm{N}_{3}\right)$, a significant (mean values of the period $24 \%$ ) increase in the activity of AcP was recorded as compared with the activity of the indicated enzyme in the soil sampled from the treatments not fertilised with nitrogen $\left(\mathrm{N}_{0}\right)$ (Fig. 1B). Dodor and Tabatabai (2003); Lemanowicz et al. (2014) found that the doses increasing up nitrogen regularly limited the activity of alkaline phosphatase, thus intensifying the activity of the acidic one.

The activity of arylsulphatase fell within the range of 0.005 to $0.582 \mathrm{mM}$

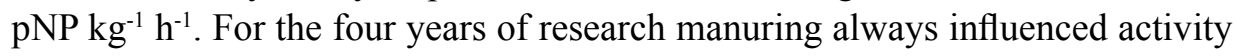
of the enzyme in the test soil. The greatest arylsulphatase activity (by an average of $0.260 \mathrm{mM} \mathrm{pNP} \mathrm{kg}{ }^{-1} \mathrm{~h}^{-1}$ ) was reported in the soil samples fertilised with FYM at the rate of $80 \mathrm{~kg} \mathrm{ha}^{-1}$. Manure at the highest dose, an average of four years of research, has increased the arylsulphatase activity by $36 \%$, compared to the control (Table 3).

The application of nitrogen fertiliser also affected the activity of that enzyme. The greatest activity of arylsulphatase in soil was found in the soil sampled from the control $\left(\mathrm{N}_{0}\right)$ and the lowest nitrate rate $\left(\mathrm{N}_{1}\right)$ (Table 3). The 
Ammonium nitrate dose $\mathrm{N}_{3}$ decreased the enzyme activity by $14 \%$. as compared with the control. The activity of arylsulphatase and the content of sulphate sulphur (VI) in soil changed in respective vegetation periods. After potato growing, there was a decrease in the content of $\mathrm{S}_{-} \mathrm{SO}_{4}^{2-}$ in the investigated soil and an increase in the activity of arylsulphatase (Table 2,3). While growing spring barley and red clover, the content of sulphates and the activity of arylsulphatase remained high. The research reported by Knauff et al. (2003) and Kotkova et al. (2008) confirm the effect of fertilisation with organic fertilisers on an increase in the activity of arylsulphatase in soil. The inhibiting effect of ammonium nitrate as well as a negative effect of ions $\left(\mathrm{NO}_{3}^{-}, \mathrm{NO}_{2}^{-}, \mathrm{PO}_{4}^{3-}, \mathrm{SO}_{4}^{2-}, \mathrm{Cl}\right)$ on the activity of arylsulphatase was observed in other research (Germida et al. 1992).

Knauff et al. (2003) showed that plants react to insufficient amount of sulphates in soil releasing arylsulphatases which make it possible for them to use organic resources of sulphur compounds. The authors found that the roots of plants growing in sterile media release arylsulphatases. The activity of that enzyme depended on the content of sulphur and increased with its high deficit.

\section{Correlation among the studied properties}

A positive correlation was reported between the content of TN and the activity of arylsulphatase $(\mathrm{r}=0.41, P<0.05)$ and the activity of that enzyme and the content of sulphate sulphur $(\mathrm{r}=0.23, P<0.05)$ in the soil (Table 4). It is common to observe a linear dependence between the activity of acid phosphatases and the amount of inorganic phosphorus forms released to the soil solution (Nannipieri et al. 2011). A high coefficient of correlation $(r=0.64, P<0.05)$ between the content of available phosphorus in soil and the activity of acid phosphatase suggests that phosphatases could be applied as an indicator of the content of phosphorus in soils (Lemanowicz 2014).

TABLE 4. THE RELATIONSHIP BETWEEN SELECTED SOIL PROPERTIES

\begin{tabular}{ccccc}
\hline \multicolumn{2}{c}{ Variables } & Equation & $\mathrm{r}$ \\
\hline Dependent & Independent & & \\
\hline Arylsulphatase activity & Total nitrogen & $\mathrm{y}=-0.1261+0.3417 \mathrm{x}$ & 0.41 \\
Acid phosphatase activity & Available phosphorus & $\mathrm{y}=0.51845+0.1516 \mathrm{x}$ & 0.64 \\
Arylsulphatase activity & Acid phosphatase activity & $\mathrm{y}=-0.0465+0.14942 \mathrm{x}$ & 0.47 \\
Sulphate sulphur & Arylsulphatase activity & $\mathrm{y}=-20.064+11.826 \mathrm{x}$ & 0.23 \\
\hline
\end{tabular}




\section{CONCLUSIONS}

1. The farmyard manure (FYM) significantly increased content of carbon, nitrogen, phosphorus, sulphur and selected hydrolases under 4-year crop-rotation. The dosage of $60 \mathrm{tha}^{-1}$ was optimal for the content of nutrients available to plants. Therefore, it can be concluded that the fertilization of farmyard manure may be considered a good practice in helping to increase soil fertility by content of elements available for plant and enzymes activity.

2. The acid phosphatase activity was influenced by ammonium nitrate fertilization treatment, and grew significantly with the increase of $\mathrm{N}$ fertilization rates. In opposite the arylsulphatase activity decreased with increasing doses of mineral fertilizer. We can therefore conclude that the acid phosphatase activity increased probably due to the acidifying effect of $\mathrm{N}$ fertilizers.

3. Intercrop white mustard and undersown crop of grasses significantly increased the investigated hydrolases activity during the 4-year crop-rotation. It can be recommended as a means of increasing soil enzymes activity.

\section{REFERENCES}

[1] A 1 korta I., A izpurua A., Riga P., A 1 bizu I., A mezaga I., Garbis u C., 2003. Soil enzyme activities as biological indicators of soil health. Revives on Environmental Health, 18(1): 65-73.

[2] B a rd s le y C.E., L a n c a s te r J.D., 1960. Determination of reserve sulfur and soluble sulfates in soil. Soil Science Society of America, 24: 265-268.

[3] B oy d S.A., Mortland M.M., 1990. Enzyme interactions with clays and clay-organic matter complexes. In: Bollag J-M. Stotzky G (eds.) Soil biochemistry, 6, Marcel Dekker. New York, pp: 1-28.

[4] D i c k R.P., 1994. Soil enzymes activities as indicators of soil quality. In: J.W. Doran and A.J. Jones (eds) Defining soil quality for a sustainable environment. SSSA Special Publication. Madison, Wl, USA, 35: 107-124.

[5] D o d o r D.E., T a b a t a b a i M.A., 2003. Effect of crop rotation systems on phosphatases in soil. Journal of Plant Nutrition Soil Science, 166: 7-13.

[6] Eriksen J., Thorup-Christen sen K., A skegard M., 2004. Plant availability of catch crop sulfur following spring incorporation. Journal of Plant Nutrition Soil Science, 167: 609-615.

[7] Ge r mida J..J, Wa in w right M., G u p t a V.V.S.R., 1992. Biochemistry of sulphur cycling in soil. Soil Biochemistry, 7: 1-53.

[8] G i a n fred a L., R u g g i e ro P., 2006. Enzyme activities in soil. In: Nannipieri P. Smalla K. (eds.) Soil Biology, 8: 257-311.

[9] Girma K., Mos ali J., Fre e man K.W., Raun W.R., Martin K.L., Thom as on W.E., 2005. Forage and grain yield response to applied sulfur in winter wheat as influenced by source and rate. Journal of Plant Nutrition, 28: 1541-1553.

[10] ISO 10390, 2005. Soil quality - Determination of $p H$. Polish Standards Committee. Warsaw Poland.

[11] Kna uff U., S chulz M., Scherer H.W., 2003. Arylsulphatase activity in the rhizosphere and roots of different crop species. European Journal of Agronomy, 19: 215-223. 
[12] Kotkova B., Balik J., C erny J., Kulkanek M., B a zalova M., 2008. Crop influence on mobile sulphur content and arylsulphatase activity in the plant rhizosphere. Plant and Soil Environment, 4: 100-107.

[13] L e m a n o w i c z J., S i w i k-Zi o m e k A., K o p e r J., 2014. Effects of farmyard manure and nitrogen fertilizers on mobility of phosphorus and sulphur in wheat and activity of selected hydrolases in soil. International Agrophysics, 28: 49-55.

[14] L i p ińs k i W., Te r e la k H., M o t o w i c k a-Te r e la k T., 2003. Suggestion for limiting values of sulphate sulphur content in mineral soils for fertilization advisory needs (in Polish). Soil Science Annual, 54(3): 79-84.

[15] Li u E., Yan C., M e i X., He W., S o H.B., D ing L., Li u Q., L i u S., F an T., 2010. Long-term effect of chemical fertilizer straw and manure on soil chemical and biological properties in northwest China. Geoderma, 158: 173-180.

[16] M a s c ag n i H.J.Jr, Harris on S.A., P a d g e t t G.B., 2008. Influence of sulfur fertility on wheat yield performance on alluvial and upland soils. Communication of Soil Science and Plant Analysis, 39: 2133-2145.

[17] Nanni pieri P., Giagn on i L., Land i L., R en ella G., 2011. Role of phosphatase enzymes in soil, in: E.K. Bunemann (Ed.) Phosphorus in Action, Soil Biology, Springer-Verlag, Berlin Heidelberg, 26: 215-243.

[18] Okur N., Kayikcioglu H.H., Okur B., Delibacak S., 2008. Organic amendment based on tobacco waste compost and farmyard manure: influence on soil biological properties and butter-head lettuce yield. Turkish Journal of Agricultural and Forestry, 32: 91-99.

[19] PN-R-04023, 1996. Chemical and Agricultural Analysis of Soil - Determining the Content of Available Phosphorus in Mineral Soils. Polish Standards Committee. Warsaw Poland.

[20] PN-ISO 11261, 2002. Soil quality - Total nitrogen assaying - Modified Kjeldahl method. Polish Standards Committee. Warsaw Poland.

[21] Samue 1 A.D., Domuta C., Sandor M., Vuscan A., Domuta C. 2010. The estimation of phosphatase activity in soil. Research Journal Agricultural Sciences, 42(3): 311-314.

[22] S cherer H.W., 2009. Sulphur in soils. Journal of Plant Nutrition of Soil Science, 172: $326-335$.

[23] Schloter M., Dilly O., Munch J.C., 2003. Indicators for evaluating soil quality. Agricultural, Ecosystem \& Environmental, 98: 255-262.

[24] Schonhof I., Blankenburg D., Müller S., Krumbein A., 2007. Sulfur and nitrogen supply influence growth, product appearance. and glucosinolate concentration of broccoli. Journal of Plant Nutrition and Soil Science, 170: 65-72.

[25] S i enki ewicz S., Krzebietke S., Wojnowska T., Żarczyński P., O milian M., 2009. Effect of long-term differentiated fertilization with farmyard manure and mineral fertilizers on the content of available forms of $P, K$ and $M g$ in soil(in Polish). Journal of Elementology, 14(4): 779-786.

[26] S o s u 1 s k i T., S tę p i eń M., S z a r a E., M e r c i k S., 2005. Content of Total Nitrogen in soils and the balance of $N$ in long - term experiments in Skierniewice(in Polish). Fragmenta Agronomica, 22 1(85): 264-273.

[27] T a b a t a b a i M.A., 1994. Soil enzymes. In: R.W. Weaver, J.R. Angle, P.S. Bottomley (eds.) Methods of soil analysis. Soil Science Society of America Book. Series 5. SSSA. Madison, WI: 775-833.

[28] T a b a t a b a i M.A., B r e m n e r J.M., 1969. Use of p-nitrophenol phosphate for assay of soil phosphatase activity. Soil Biology \& Biochemistry, 1: 301-307.

[29] T a b a t a b a i M.A., B r e m n e r J.M., 1970. Factors affecting soil arylsulphatase activity. Soil Science Society of America Proceeding, 34: 427-429.

[30] Ż e brow ska E., C i e re s z k o I., 2009. Acid phosphatases role in plant cells phosphate homeostasis (in Polish). Advances in Cell Biology 36: 583-599. 